\title{
Investigating the Cooperation Status Between the Health System and City Councils and Municipalities in Iran (Documents' Analysis)
}

Najmeh Khodadadi ( $\nabla$ khodadadi.n@iums.ac.ir)

iran University of Medical Sciences https://orcid.org/0000-0002-5655-9183

Aidin Aryan Khesal

iran University of Medical Sciences

Mohamad Reza Maleki

iran University of Medical Sciences

Research article

Keywords: Health, Municipality, City Council, Cooperation, Iran

Posted Date: June 22nd, 2020

DOI: https://doi.org/10.21203/rs.3.rs-35625/v1

License: (c) (i) This work is licensed under a Creative Commons Attribution 4.0 International License.

Read Full License 


\section{Abstract}

Background: The present study is aimed at investigating the cooperation status between the health system and city councils and municipalities in Iran based on rules and documents.

Methods: Altheide's document analysis model (sample selection, data collection, data organization, data analysis, and reporting) was employed in order to prepare and analyze the documents pertaining to the cooperation level between the health system and municipalities and Islamic city councils. The documents were classified at three levels including the national rules, policies, and guidelines; Ministry of Health $(\mathrm{MOH})$ and city council approvals; and eventually Tehran Municipality's measures.

Results: Overall, 78 documents were analyzed including 17 documents at the level of national rules, policies and guidelines; 8 documents at the level of Ministry of Health and city council approvals; and 53 documents at the level of Municipality's measures.

Conclusion: There are adequate legal capacities for designing, planning, executing, as well as creating interaction and cooperation between health system and city councils and municipalities. Moreover, the motive behind creating a purposeful and scheduled cooperation and participation is evident among the officials of health system and city councils and municipalities. Some mechanisms have been established for cross-sectoral cooperation between the health system and other health-related bodies on a crosssectional basis, but these structures lack the necessary competence, appropriateness and adequacy to create the desired partnership, and especially sufficient attention to existing capacities in municipalities and The city council has not. Accordingly, it is necessary to have a fundamental review on the available structures and enough attention has to be paid to the evident and hidden legal capacities in city councils, and municipalities, as well as Ministry of Health to design an appropriate structure and create competent interaction and also provide more cooperation between the two organizations.

\section{Introduction}

Population growth on the one hand and increasing demand and need to health services and healthrelated costs on the other hand have made the health issue's policy makers and international communities to conclude that health system and municipalities and Islamic city councils as two important and strategic organizations should work together and proceed along with each other with serious cooperation and interaction in line with health objectives $(1,2)$. In the UK, this kind of cooperation is designed and executed in a purposeful manner through creation of London cooperation group (3). In Scandinavian countries, Ministry of Health has given some of its duties over municipalities and it acts as a policy maker and examines them (4).

In Iran, all health care services, from policy-making to implementation and monitoring, are all the responsibility of the Ministry of Health. All service centers, even health centers in rural areas, provide services under the supervision of medical universities. Municipalities have no duty to provide health services, and medical services in municipalities are provided only for staff working in the municipality. 
Municipalities often take action in the field of health, which is often appropriate and usually not based on the priorities of the Ministry of Health. Many actions are taken simultaneously and jointly by the municipality and the universities of medical sciences, which means parallel activities and wasted resources.

Examining the documents available in the three sections of rules and regulations, city council approvals and municipal actions shows important points. The present study is aimed at addressing the question of to what extent the cooperation between Ministry of Health and city councils, and municipalities in Iran have been included and supported in the rules, policies, and guidelines and also executive programs.

\section{Material \& Methods}

Altheide's 5-stage document analysis model was implemented for investigating the status of cooperation between Ministry of Health, city councils, and municipalities in Iran (6ه5). The stages included sample selection, data collection, data organization, data analysis, and reporting (Fig. 1).

\section{Fig. 1: Altheide's 5-stage document analysis}

\section{First stage: Sample Selection}

The examined documents in the present study included the rules, policies, and guidelines and approvals and planning pertaining to the cooperation between Ministry of Health and city councils and municipalities which were available to the public. The documents were classified in three sections of rules and regulations, city council approvals and municipal actions. Among all municipalities, the actions of Tehran Municipality as the capital and metropolis were examined. These documents were searched from the national official websites and relevant professional organizations.

\section{Inclusion and Exclusion Criteria}

Among the obtained documents, the approvals and documents were exclusively examined which in a way contained the concept of cooperation, and participation between Ministry of Health, and city councils and municipalities. In case the rules had modifications, only those modifications were employed. For the documents pertaining to Tehran's municipality measures, only the measures relevant to the years 2011 to 2018 were included in the study based on the wide range of activities.

\section{Second stage: Data Collection}

The national rules, policies and guidelines were obtained by searching through the website of Islamic Parliament of Iran, Parliament Research Center, Academy of Medical Sciences, Ministry of Interior, Supreme Council of Provinces, and National Rules and Regulations System. The documents pertaining to Ministry of Health and city council were collected through referring to the websites of Ministry of Health, the portal of the Ministry's Social Affairs Department, the National Base of Health Rules and Regulations, the website of Tehran Council, the Health and Social Commissions of the City Council, as well as the 
comprehensive system of approvals of the council of Tehran. With regard to the documents related to the measures of Tehran's municipality, the website of the municipality and Portal of Tehran Municipality Health Department were checked. The keywords including health, hygiene, memorandum, cooperation, municipality, city council, medicine, and treatment were employed.

\section{Third level: Data Organization}

At this stage, all the obtained data and documents were classified in three groups of national rules, policies, and guidelines; the approvals of Ministry of Health and city council; and Tehran Municipality measures.

\section{Fourth stage: Data Analysis}

At this stage, the obtained data analysis in all three groups was done using 10 NVivo (QSR International: accessed 2 November 2016). The table of notes and data was employed for making a comparison between the documents in each group and between the three groups. The concluding remarks were combined and the research intended points were obtained.

\section{Fifth stage: Report}

At this stage, the key concepts and findings were combined and the researcher interpreted the findings.

\section{Results}

All the relevant websites and databases were equipped with search engine and were able to search the keywords. The documents' selection was carried out at two stages. In the first stage of the search, 26283 documents were obtained among which, 26005 were irrelevant considering the scope of the research and accordingly 2785 remained. At the second stage, among the documents of the first and second groups (the documents related to national rules, Ministry of Health, and Tehran Municipality measures), and among the documents of the third group (Tehran Municipality measures), 3 documents due to having modification and 197 documents due to being referred to the years before 2011 and after 2018 were excluded, respectively. Eventually, 78 documents were analyzed which respectively included 8 and 53 documents related to Ministry of Health and Tehran council, and the measures and performance of Tehran Municipality (Fig. 2).

With regard to the national rules, policies, and guidelines, 17 documents were obtained as follows: the municipalities law approved in 1955; the statute of the Academy of Medical Sciences of the Islamic Republic of Iran approved in 2000; the vision, mission and strategic programs of the Academy of Medical Sciences of the Islamic Republic of Iran approved in 2000; the objectives of Health Futurology and Theorizing council of Ministry of Health of the Islamic Republic of Iran approved in 2000; the memorandum of Ministry of Health and Tehran Municipality to form Tehran Health Strategic council in 2013; the approvals of the meetings in Tehran Health Strategic council; general health policies on behalf of the Supreme Leadership Authority approved in 2014; the statute of the Islamic Republic of Iran 
approved in 1979; 2025 vision document of the Islamic Republic of Iran approved in 2009; the national document of development of the health sector in the fourth national development program approved in 2004; the executive guideline of the National Assembly of Health and Provincial Health Assembly approved in 2016; and finally the regulation on the formation of the National and Provincial Health and Food Safety supreme council approved in 2018.

The approvals of Ministry of Health and city council include the following 8 relevant documents: the necessity of reviewing the bill of the statute of Tehran Municipality Health Services Organization within the approved framework of Comprehensive Organization of Social and Cultural Affairs of Tehran Municipality by the commission of Economy, Planning and Budget, and Legal Affairs of the city council approved in 2000; giving a permission to Tehran Municipality to purchase a 3D ultrasound and delivering it to Tehran University of Medical Sciences and Health Services to be used by citizens in 2001; giving a permission to Tehran Municipality to equip the library of Tehran University of Medical Sciences and Health Services up to the maximum amount of 500.000.000 Rials from the approved credits of the deputy of Social and Cultural Affairs of Tehran Municipality in 2001 budget of Tehran Municipality; changing the name of Tobacco alley to Health alley in 2012; the necessity of launching health, safety and environment management system by Tehran Municipality in 2013; proposing to the government and parliament to provide the required budget for Ministry of Health, and Medical Education for disposal of medical-specific wastes in 2010; and finally the certificate of definitive transfer of Tehran Municipality lands ownership to Tehran' south health center in 2000. It is noteworthy that all the mentioned approvals regard Tehran city council and there is no approval concerning Ministry of Health.

Among the measures compatible with the scope of the research, 53 cases were obtained which have been carried out since 2011 to 2018 in Tehran Municipality. These measures have all been done in various national occasions such as national week of elderly or based on the announced slogans by international communities including WHO.

\section{Discussion:}

Based on 2025 vision document of the Islamic Republic of Iran, for achieving the objectives, i.e. having health, welfare, food safety, social security, equal opportunities, revenue appropriate distribution, strong family institution; being away from poverty, chaos, discrimination; and enjoying desirable environment cannot be achieved unless a cross-sectoral cooperation and participation exists between the relevant organizations and concerning the health sector, there is no way but creating purposeful and scheduled cooperation and interaction between health system and city councils and municipalities (7). In healthcare sector, in the fourth national development program, and also the general policies of health, the Supreme Leadership Authority has also referred to this important issue $(8,9)$.

In 2017, National Health Assembly was formed on behalf of Ministry of Health with the aim of popularizing health and explaining the role of other institutions including municipality in line with

promoting health $(10,11)$. In addition, Supreme Council of Health and Food Security (SCHFS) was 
formed (12). National Health Assembly and Supreme Council of Health and Food Security have been formed in all provinces and cities and the members of city councils and municipalities have the membership of these two councils too.

One of the important points that was obtained through examining the documents was that in none of the available documents, a structure or position is observed for creating cooperation and interaction between city council and municipality, and health system. Moreover, in the mechanisms formed for creating a cross-sectoral interaction and cooperation between Ministry of Health and other organizations including National Health Assembly, Supreme Council of Health, and Strategic Council of Health, there has been minimum attention to the capacities and capabilities of city councils and municipalities for promoting citizens' health status.

Through reviewing the available documents related to national rules and regulations, it can be observed that according to article 29 of the Constitution, the government is obliged to provide people with healthcare services form public revenues, as well as revenues form people's participation (13). A significant part of municipalities' revenues is gained from public revenues and also the revenues resultant form people's participation; as a result, city councils and municipalities are obliged to present a precise program in line with promoting citizens' health and the expenditures have to be reviewed based on national health policies.

According to articles 4, 6, and 15 of municipalities law approved in 1956/01/25, municipalizes are obliged to consider the health affairs of citizens and cooperate with the institutions of Ministry of Health; therefore, adequate authority and responsibilities have been determined for municipalities in healthrelated affairs (14). Based on the statute of the Academy of Medical Sciences of the Islamic Republic of Iran (15), and the mission developed for it, the academy has the required authority and responsibility to predict, explain, and take measures in line with creating cooperation and interaction between city councils and municipalities and health system or even creating an appropriate structure with explaining the duties in a clear manner along with examining its performance $(16,17)$.

Although Tehran Health Strategic council has been formed with the goal of promoting health in Tehran following the conclusion of a memorandum between Ministry of Health and Tehran Municipality (18) presided over by the head of Academy of Medical Sciences and membership of senior officials of Ministry of Health and some other relevant organizations, on behalf of city councils and municipalities, instead of the presence of the senior officials in decision making affairs, the head of Health and Welfare Committee has joined as a member in this council (19). It seems that the importance and position of the abovementioned council is in a way that the membership and presence of the head of city council and municipalities is considered more effective in important decision makings concerning citizens' health.

In investigating the documents related to Tehran Municipality approvals, it was observed that in spite of the existence of appropriate legal grounds and wide range of capacities and also the inclination towards taking measures in health filed by city council and Tehran Municipality on the one hand, and the increasing needs and lacks of the health system, there has been only 8 approvals among various 
approvals of city council so far since the formation of Tehran city council in 1997 on the other hand. This indicates the cooperation level of city council and municipality with the Health system which also reveals the negligence of the health system in employing the capabilities of city council or municipality in the health promoting field. Among the above-mentioned 8 approvals, two cases regard the physical needs $(20,21)$; one case regards equipment provision for services offering (22); two cases concern cultural measures for the health sector $(23,24)$; one case is about the recommended measures to the superior and legislature sectors (25); and two cases regard the necessity of implementation of some activities concerning health $(26,27)$ by municipality and city council.

Reviewing the documents pertaining to municipality measures shows that the officials and policy makers both in Ministry of Health, and city council and municipality, have reached the conclusion that for fulfilling the objectives of a community's health and its improvement, interaction and cooperation should be created between these two important institutions which includes Ministry of Health as the major policy maker and agent of the community and city council and municipality as the policy maker and fist-line executor of access to and communication with local community. These documents demonstrate that in Iran, the first step for reaching this strategic objective (interaction and cooperation) which is understanding the necessity and feeling need has been considered and an acceptable understanding has been created by both parties, i.e. Ministry of health and city council and municipality $(28,29)$.

Among these documents, the cooperation memorandum is available which has been concluded among Ministry of Health and municipality (2013/12/27) (30). Subsequently, in separate interviews, the officials of Ministry of Health emphasize on the importance and necessity of employing cross-sectoral cooperation, particularly making use of the capacities and capabilities of the city council and municipality for improving the health status of citizens $(31,32)$. The head of Academy of Medical Sciences, who is at also a member of the Health Commission of the Parliament, refers to the formation of the Strategic Council of Health on 2014/2/7 in order to make changes in the health status of citizens (29). Eventually, on 2014/2/16, the first meeting of Tehran Strategic Council of health is formed in Academy of Medical Sciences (28) and following that, the next meetings are hold in turn aimed at compiling the statutes and strategies of council $(32,33)$. In the same vein, city council and municipality also take measures with the aim of creating interaction and cooperation with Ministry of Health as health general directorate of Tehran Municipality has concluded a cooperation document with Tehran University of Medical Sciences on 2018/9/19 (34). These documents are indicator of understanding the need and necessity of an interaction and cooperation between these two influential intuitions by both parties.

Some internal documents also show that despite figuring out the importance of the correlation and the necessity of cross-sectoral interaction to promote citizens' health, the capacities of city council and municipality are not taken into consideration as they should be. In Strategic Council of Health, the head is elected by minister of Health and the other members are as the following: Vice-Chancellor in Health Affairs, Vice-Chancellor in Treatment Affairs, Deputy Minister for Universities Affairs, Director General for International Affairs, Head of Public Relations and Information Center of Ministry of Health, head of Shahid Beheshti University of Medical Sciences, head of University of Social Welfare and Rehabilitation 
Sciences, head of Iranian Health Insurance Organization, World Health Organization representative, Director General for the Medical System Organization, the head of Health and Welfare Committee of Tehran City Council, and many real members. As it is evident, among Tehran city council and municipality, just the head of Health and Welfare Committee of city council is a member of this important council in spite of the existence of a wide range of capacities (28). However, in case London corporation group is formed in London, the mayor is considered at the position of the head of group and it seems that the UK officials have figured out the wide range of the capacities and potentials of municipalities as the frontline of dealing with the people of community seriously (4) which has not been much attended in Iran.

The documents show the wide range of activities carried out by municipalities in health-related issues which implies high budget expenditure in this regard. The serious question now is how much of the mentioned activities is based on the priorities of Ministry of Health, and basically whether the policies of Ministry of Health are communicated with this influential and active institution in the field of health (35). The available evidence and documents show that these large-scale activities are more compatible with occasions than the policies of Ministry of Health or even the city's indigenous priorities. The mentioned occasions include national, international and World Health Organization occasions. Among the various measures of Tehran Municipality in this regard, the following cases can be named: Special programs for National Men's Health Week $(36,37)$, National Women's Health Week $(38,39)$, Elderly Week $(40,41)$, World Mental Health Day $(42,43)$, World Heart Week for Children $(44,45)$, World Health Day $(46,47)$, Commemoration of National Health Week $(48,49)$, National Week without Tobacco $(50)$, Health in the Holy Month of Ramadan (51), National Diabetes Week $(52,53)$, National Anti-Cancer Week $(54,55)$ and Doctor's Day (56).

The documents are indicator of the fact that municipality possesses significant capacities in addition to the capabilities for taking measures based on occasions. The mentioned capacities include employing local professional workforce in the field of health $(57,58)$, using international capacities to promote health $(59,60)$, providing preventive and screening services $(61,62)$, cooperating with national macro plans in the field of health (63), taking action to promote the health of needy citizens $(64,65,66)$, taking action to promote the health of certain groups $(38,66,45)$, improving the level of public awareness in the field of health $(67,68)$, building permanent places to provide services and improve citizens' health $(69$, $70)$, providing some determined health-related services extensively $(71,72,73)$, empowering the status of creating conditions appropriate for students' education in the field of community-based health, or in other words, education based on sociology of health (74), taking actions to achieve the national macro-policies which are related to community health including lifestyle changes and strengthening family foundation $(75,76,77)$, empowering the condition to create synergy of health service providing sectors (78), meeting the needs of local health providing service units $(79,80)$, empowering the status to change citizens' viewpoints to prioritize health among citizens $(81,82)$, empowering the status to create the required grounds for providing cheap services to the general public $(83,84)$, and empowering the status to create the necessary conditions to improve the capabilities of health activists (85). 
Another important issue which was evident is that in spite of understanding the necessity of cooperation with each other in this regard, the officials of Ministry of Health, and city council and municipality still act based on their specific duties and diagnosis which is the factor for many parallel and repetitive measures resulting in wasting resources. Most of the significant measures taken by municipality are also undertaken by various units of Ministry of Health simultaneously which include most occasional programs, employing the capability of charity organizations, providing services, making an attempt to promote the health-related awareness of the community, and providing services to needy groups in the form of volunteer groups $(86,87)$.

Each organization makes use of various resources including human resources, financial resources, etc. for the mentioned measures that at the same time, consolidating resources and taking actions according to certain predetermined policies will double the country's success in ensuring people's health. This indicates the gap of existence of a clear and determined structure for forming mutual interaction as well as cooperation between the health system and councils and municipalities. It is clear that in case this kind of mechanism is created, most of the repetitive actions and accordingly the resources waste will be removed. With the formation of Strategic Council of health, there was a hope to form an effective mechanism; however, in the available documents, no official and legal structure is observed with the required executive capability.

\section{Concluaion:}

There are adequate legal capacities for designing, planning, executing, and creating cooperation and interaction-specific structure between the health system, and city council and municipalities $(14,13)$. There is also the necessary motive behind creating purposeful and scheduled cooperation between the officials of Ministry of Health and city councils and municipalities $(18,34)$. There are also mechanisms for creating cross-sectoral cooperation between health system and other health-related institutions; however, in these structure, the capacities of municipalities and city councils have not been employed as they should be. As a result, either a determined structure for this important issue should be designed, or the available structures should be reviewed $(28,11)$.

\section{Declarations:}

\section{Declarations}

1. Ethics approval and consent to participate: This article has received the code of ethics from the ethics committee of Iran University of Medical Sciences:IR.IUMS.REC.1397.919

2. Consent for publication: Not applicable

3. Availability of data and materials: All data generated or analyzed during this study are included in this published article [and its supplementary information files].

4. Competing interests: The authors declare that they have no competing interests. 
5. Funding: This article is taken from a specialized doctoral dissertation and will not be charged.

6. Authors' contributions: All authors read and approved the final manuscript.

7. Acknowledgements: Not applicable.

\section{References}

1. Webster $P$, Sanderson D. Healthy cities indicators-a suitable instrument to measure health? Journal of urban health. 2013;90(1):52-61.

2. Davey KJ. Elements of urban management: The World Bank; 1993.

3. London health devolution agreement. 2017 [updated 22 November 2017; cited 2019. Available from: https://www.gov.uk/government/publications/london-health-devolution-agreement/london-healthdevolution-agreement.

4. Khangah HA, Jannati A, Imani A, Salimlar S, Derakhshani N, Raef B. Comparing the health care system of Iran with various countries. Health Scope. 2017;6(1).

5. Altheide DL. Process of qualitative document analysis. In: Qualitative media analysis. Thousand Oaks: California; 1996. pp. 23-41.

6. Altheide DL, Schneider B. Process of qualitative document analysis. Qualitative media analysis. 2nd ed. pp. 39-74. Thousand Oaks: California; 2013.

7. Perspective of the Islamic Republic of Iran in 1404. http://farsi.khamenei.ir/message-content? id $=9034$. Accessed 3/20/2020.

8. The Supreme Leader. of the Revolution announced the general health policies of 2014. http://farsi.khamenei.ir/news-content?id=26083. Accessed2020/30/5.

9. National Document for the Development of the Health Sector in the Fourth Development Plan of. 2009. https://www.ilo.org/dyn/natlex/docs/ELECTRONIC/91720/106519/F2093574466/IRN91720.pdf. Accessed2020/30/5.

10. Popularize health care; Among the duties of the Health Assembly. 2017. https://behdasht.gov.ir/. Accessed 3/20/2020.

11. Executive instructions of the National Assembly of Health and the Health Assembly of the province and the city of 2017 Accessed 3/20/2020.

Executive instructions of the National Assembly of Health. and the Health Assembly of the province and the city of 2017. http://farhangi.tums.ac.ir. Accessed 3/20/2020.

12. Regulations on the formation of the Supreme Council of Health. and Food Safety of the country, province, city of 2009. https://rc.majlis.ir/fa/law/show/126527. Accessed 3/20/2020. Constitution of the Islamic Republic of Iran. https://rc.majlis.ir/fa/content/iran_constitution. Accessed2020/30/5.

13. Municipal Law approved in 1334. https://rc.majlis.ir/fa/law/show/94737. Accessed2020/30/5.

14. Statute of the Academy of Medical Sciences of the Islamic Republic of Iran. approved in 1989. https://rc.majlis.ir/fa/law/show/100020. Accessed 3/20/2020. 
15. mission and strategic plans of the Academy of Medical Sciences of the Islamic Republic of Iran Accessed 3/20/2020.

Perspective. mission and strategic plans of the Academy of Medical Sciences of the Islamic Republic of Iran. http://www.ams.ac.ir/index.php/2013-11-07-08-10-52. Accessed 3/20/2020.

16. Future Development Council and Health Theory. http://www.ams.ac.ir/index.php/2013-11-11-13-2225. Accessed2020/30/5.

17. Concluding a memorandum of cooperation between Tehran Municipality and the Ministry of Health. in 2013. https://www.magiran.com/article/2873629. Accessed 3/20/2020.

18. Amendment of the resolution

approving the definitive transfer of the land ownership document of Tehran Municipality to the South Health Center Accessed2020/30/5.

Amendment of the resolution. approving the definitive transfer of the land ownership document of Tehran Municipality to the South Health Center. http://laws.tehran.ir/Law. Accessed2020/30/5.

19. Permission to transfer the ownership document of Tehran Municipality to the South Tehran Health. Center in 2000. http://laws.tehran.ir/Law. Accessed2020/30/5.

20. Amendment of the resolution approving the definitive transfer of the land ownership document of Tehran Municipality to the South Health Center Accessed2020/30/5.

Amendment of the resolution. approving the definitive transfer of the land ownership document of Tehran Municipality to the South Health Center. http://laws.tehran.ir/Law. Accessed2020/30/5.

21. Permission to Tehran

Municipality to purchase a three-dimensional ultrasound machine and deliver it for use to Tehran University of Medical Sciences and Health Services for the use of citizens Accessed 3/20/2020.

Permission to Tehran. Municipality to purchase a three-dimensional ultrasound machine and deliver it for use to Tehran University of Medical Sciences and Health Services for the use of citizens. http://laws.tehran.ir/Law. Accessed 3/20/2020.

22. Renamed the tobacco neighborhood. located in the 11th district of Tehran Municipality. http://laws.tehran.ir/Law. Accessed2/10/2020.

23. Permission to Tehran Municipality to equip the library of Tehran University of Medical Sciences and Health Services. http://laws.tehran.ir/Law. Accessed2/10/2020.

24. Proposing to the government. and the Islamic Consultative Assembly to provide the required budget for the Ministry of Health. http://laws.tehran.ir/Law. Accessed 3/20/2020.

25. Requirement of. Tehran Municipality to establish a health, safety and environmental management system. http://laws.tehran.ir/Law. Accessed 3/20/2020. 
26. Requirement of the Economic Commission. Program and Budget and Legal Affairs of the City Council to review the statute of the Tehran Municipality Health Services Organization. http://laws.tehran.ir/Law. Accessed 3/20/2020.

27. The first meeting of Tehran Strategic Health Council. in2013.https://iums.ac.ir/content/3287. Accessed2020/30/5.

28. Establishment of the Strategic Council. of "Health" in Tehran / Great change in the "health" of the country with the establishment of the Strategic Council in 1392. https://www.yjc.ir/fa/news/4723832. Accessed4/05/2020.

29. Concluding a memorandum of cooperation between Tehran Municipality and the Ministry of Health. in 2013. https://www.magiran.com/article/2873629. Accessed 3/20/2020.

30. Coverage of primary health care in metropolitan areas is on the agenda of the Strategic Health Council. https://snn.ir/fa/news/290264. Accessed4/12/2020.

31. Resolving the health problems. of the suburbs of the metropolis is a priority of the Strategic Council of Tehran in 2013. https://www.irna.ir/news/81023968. Accessed4/05/2020.

32. 16th meeting of Tehran City Strategic Health Council. 2013. http://www.ams.ac.ir/index.php/201311-12-06-01-40/757. Accessed2020/30/5.

33. Signing of a joint cooperation document between the General Directorate of Health and Tehran University of Medical Sciences. 2019. http://farhangi.tehran.ir/default.aspx?tabid=81\& Articleld = 101418. Accessed 3/20/2020.

34. Improving the health. sector, the priority of the city council in metropolitan areas / the need to pay attention to the policies of the Ministry of Health in the field of health. http://laws.tehran.ir/Law. Accessed 03/20/2019.

35. Special announcement of Tehran Municipality's programs in the National Men's Health Week. 2019. http://farhangi.tehran.ir/Default.aspx?tabid=777. Accessed2/10/2020.

36. 90 Men's Health-Based Programs. 2017. http://farhangi.tehran.ir/Default.aspx?tabid=777. Accessed $3 / 20 / 2019$.

37. Move. for Women's Health "in 22 districts of the capital 2018. http://farhangi.tehran.ir/Default.aspx? tabid=777. Accessed2/10/2020.

38. Specialized. conference "Healthy lady, healthy family, healthy city" 2014. http://farhangi.tehran.ir/default.aspx?tabid=81\&Articleld=69663. Accessed 03/20/2019.

39. "How to. work with the elderly" training for health educators in the 22 districts of 2019. http://farhangi.tehran.ir/Default.aspx?tabid=777. Accessed2/10/2020.

40. Aging Conference in Region 22 Health. and Aging Conference in Region 22 2014. http://farhangi.tehran.ir/default.aspx? tabid=81\&Articleld=69004. Accessed 23/10/2019.

41. Health and Lifestyle Conference. 2016. http://farhangi.tehran.ir/default.aspx? tabid=81\&Articleld=91101. Accessed 23/10/2019. 
42. Conference "The Role of Health Homes in Improving the Mental Health of Citizens" 2013.

43. http://farhangi.tehran.ir/default.aspx?tabid=81\&Articleld=49541. Accessed 23/10/2019.

44. Free Children's Heart Visit. 2017. http://farhangi.tehran.ir/default.aspx?tabid=81\&Articleld=92851. Accessed 03/20/2019.

45. Specialized conferences of the "Heart of the Child". World Week in the districts of District 192017. http://farhangi.tehran.ir/default.aspx?tabid=81\&Articleld=92788. Accessed 03/20/2019.

46. Holding a "Health Festival" in Mellat Park. 2017. http://farhangi.tehran.ir/Default.aspx?tabid=777. Accessed 02/10/2020.

47. Free services by the medical and psychological team in the deprived. areas of 2017. http://farhangi.tehran.ir/default.aspx?tabid=81\&Articleld=93131. Accessed2/10/2020.

48. "Health Festival" in Mellat Park. 2017. http://farhangi.tehran.ir/Default.aspx?tabid=777. Accessed 3/20/2019.

49. Health Festival to serve the citizens of the south of the city 2017 Accessed 3/20/2019. Health Festival to. serve the citizens of the south of the city 2017. http://farhangi.tehran.ir/Default.aspx?tabid=777. Accessed 3/20/2019.

50. Free medical services during the National Week without Tobacco. in District 192017. http://farhangi.tehran.ir/Default.aspx?tabid=777. Accessed 3/20/2019.

51. Implementing the Health Plan at. the 2017 Banquet. http://farhangi.tehran.ir/Default.aspx? tabid=777. Accessed 3/20/2019.

52. Selection of famous artistic and sports figures as cultural ambassadors of Diabetes. 2019. http://farhangi.tehran.ir/Default.aspx?tabid=777. Accessed2/10/2020.

53. Commemoration of National Diabetes Week in Tehran Municipality. 2018. http://farhangi.tehran.ir/Default.aspx?tabid=777. Accessed2/10/2020.

54. Implementation of the national. movement "Fighting Cancer" in Tehran in 2019. http://farhangi.tehran.ir/Default.aspx?tabid=777. Accessed2/10/2020.

55. 2015 Breast Cancer Prevention Conference. http://farhangi.tehran.ir/Default.aspx?tabid=777. Accessed 3/20/2019.

56. Celebration of Hakim Abu Ali Sina and Doctor's Day in. Region 92014. http://farhangi.tehran.ir/default.aspx?tabid=81\&Articleld=67282. Accessed 23/10/2019.

57. Mobilizing social capacities. to hold a "health festival" in Bustan Bahman 2017. http://farhangi.tehran.ir/Default.aspx?tabid=777. Accessed 3/20/2019.

58. The maneuver of the big team. of Region 7 Physicians Association was held in 2017.

59. http://farhangi.tehran.ir/default.aspx?tabid=81\&Articleld=93134. Accessed 02/10/2020.

60. Healthy City Symposium. 2012. http://shahraneh.blogfa.com/post/47. Accessed 3/20/2020. 
61. Commencement of joint cooperation between the National Commission for UNESCO and the Social. and Cultural Deputy of Tehran Municipality in the field of citizenship rights and the promotion of urban accessibility in 2019. http://farhangi.tehran.ir/Default.aspx?tabid=777. Accessed2/10/2020.

62. AIDS bus and screening 116 citizens. 2016. http://farhangi.tehran.ir/default.aspx? tabid=81\&Articleld=92514. Accessed 03/20/2019.

63. Diabetes Bus Host Citizens. 2016. http://farhangi.tehran.ir/default.aspx?tabid=81\&Articleld=92521. Accessed 03/20/2019.

64. The first session of the Health Transformation Plan. 2016. http://farhangi.tehran.ir/default.aspx? tabid $=81 \&$ Articleld=91295. Accessed 30/10/2019.

65. Start new lifestyle. courses in the south of the city with health-oriented topics 2017. http://farhangi.tehran.ir/Default.aspx?tabid=777. Accessed 3/20/2019.

66. Specialized examinations of 800. citizens in 2017. http://farhangi.tehran.ir/Default.aspx?tabid=777. Accessed 3/20/2019.

67. The 1,000th deprived citizen of District 16. received health services in 2017. http://farhangi.tehran.ir/default.aspx?tabid=81\&Articleld=92834. Accessed 03/20/2019.

68. District 21 Permuz Center is operational in. 2017. http://farhangi.tehran.ir/default.aspx? tabid=81\&Articleld=92589. Accessed 28/12/2019.

69. Power bus for citizens of the capital north. 2017. http://farhangi.tehran.ir/default.aspx? tabid=81\&Articleld=92638. Accessed 01/02/ 2019.

70. Start of health village in Ghaem Park. District 2017. http://farhangi.tehran.ir/Default.aspx? tabid=777. Accessed2/10/2020.

71. Guide to providing. health home services in the meeting of health managers of 22 districts of Tehran. http://farhangi.tehran.ir/Default.aspx?tabid=777. Accessed2/10/2020.

72. Providing health-oriented services. in 2018 metro stations. http://farhangi.tehran.ir/Default.aspx? tabid=777. Accessed2/10/2020.

73. More. than 200,000 citizens benefit from the municipality's health-oriented programs in 2017. http://farhangi.tehran.ir/Default.aspx?tabid=777. Accessed 3/20/2019.

74. More than 500 citizens enjoy the free services of Pardis Khidmat Mahallat Campus in the north of Tehran 2017 Accessed2/10/2020.

More than 500 citizens enjoy the free services of Pardis. Khidmat Mahallat Campus in the north of Tehran 2017. http://farhangi.tehran.ir/default.aspx?tabid=81\&Articleld=93151. Accessed2/10/2020.

75. New Diabetes Student Conference organized by the District 22 Health Department. http://farhangi.tehran.ir/default.aspx?tabid=81\&Articleld=67283. Accessed 23/10/2019.

76. Start new lifestyle. courses in the south of the city with health-oriented topics 2017. http://farhangi.tehran.ir/Default.aspx?tabid=777. Accessed 3/20/2019. 
77. Special "Healthy and Happy Life". 2017 programs. http://farhangi.tehran.ir/Default.aspx?tabid=777. Accessed2/10/2020.

78. Strengthening the Family. Foundation" workshop in the houses of the neighborhoods. http://farhangi.tehran.ir/default.aspx?tabid=81\&Articleld=92787. Accessed 03/20/2019.

79. Fair promotion of health depends on the consensus. and synergy of the service providers in 2015. http://farhangi.tehran.ir/default.aspx?tabid=81\&Articleld=75805. Accessed 03/20/2019.

80. Signing of a joint cooperation document between the General Directorate of Health and Tehran University of Medical Sciences. 2019. http://farhangi.tehran.ir/default.aspx?tabid=81\& Articleld = 101418. Accessed 3/20/2020.

81. Troubleshooting Milad Hospital by the Deputy Mayor for Social Affairs. 2014. http://farhangi.tehran.ir/default.aspx?tabid=81\&Articleld=62135. Accessed 23/10/2019.

82. Providing health-oriented services to citizens in Razi Park. 2017. http://farhangi.tehran.ir/Default.aspx?tabid=777. Accessed2/10/2020.

83. Providing medical and counseling services to citizens. 2017. http://farhangi.tehran.ir/Default.aspx? tabid=777. Accessed2/10/2020.

84. Visit and monitor the beam centers. 2018. http://farhangi.tehran.ir/Default.aspx?tabid=777. Accessed2/10/2020.

85. Free visit and services of Moayeri Hospital. 2018. http://farhangi.tehran.ir/Default.aspx?tabid=777. Accessed 3/20/2019.

86. Holding courses to improve the educational abilities of health activists in Tehran Municipality. 2019. http://farhangi.tehran.ir/Default.aspx?tabid=777. Accessed2/10/2020.

87. Screening of risk assessment and paraclinical tests on the occasion of the National Iranian Men's Health Week. 2019.http://bazresi.tums.ac.ir/index.jsp? siteid $=22 \&$ fkeyid $=\&$ siteid=22\&pageid=531\&newsview $=85407$. Accessed 3/15/2019.

88. The role of Jahrom University of Medical Sciences students in. the 2019 voluntary health camp. http://mefda.ir/news/97253. Accessed 7/5/2019.

\section{Figures}




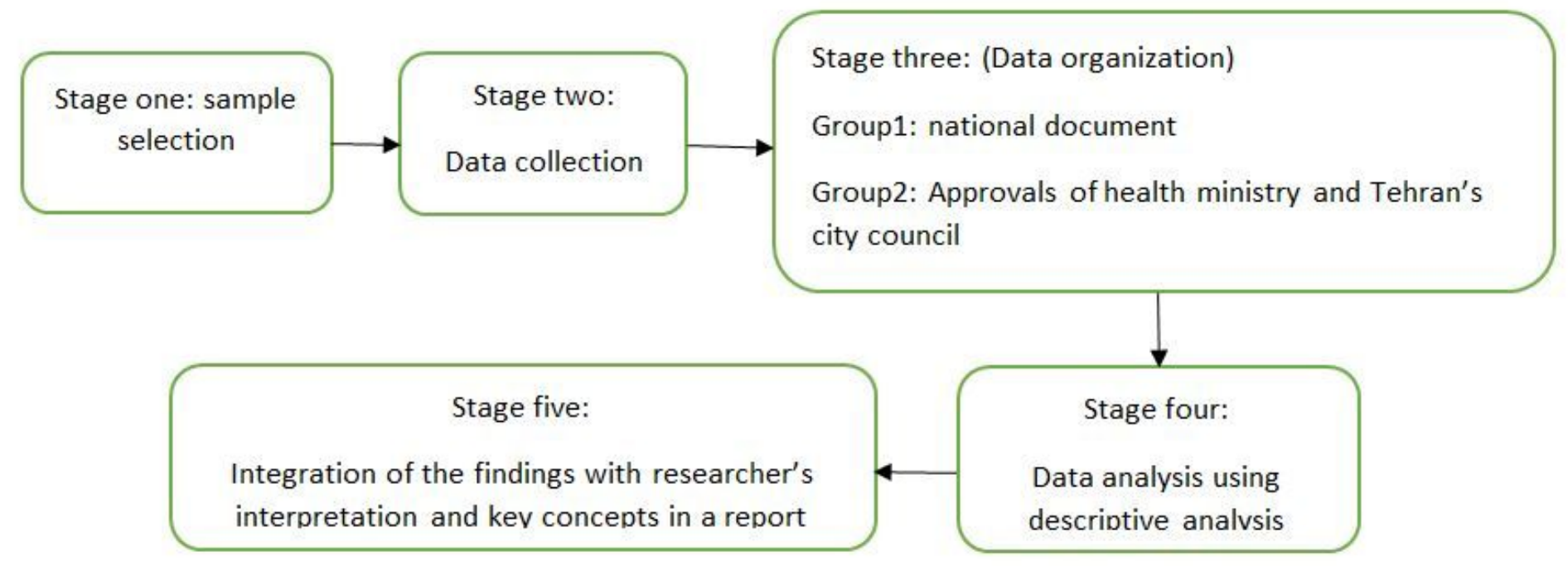

\section{Figure 1}

Altheide's 5-stage document analysis 


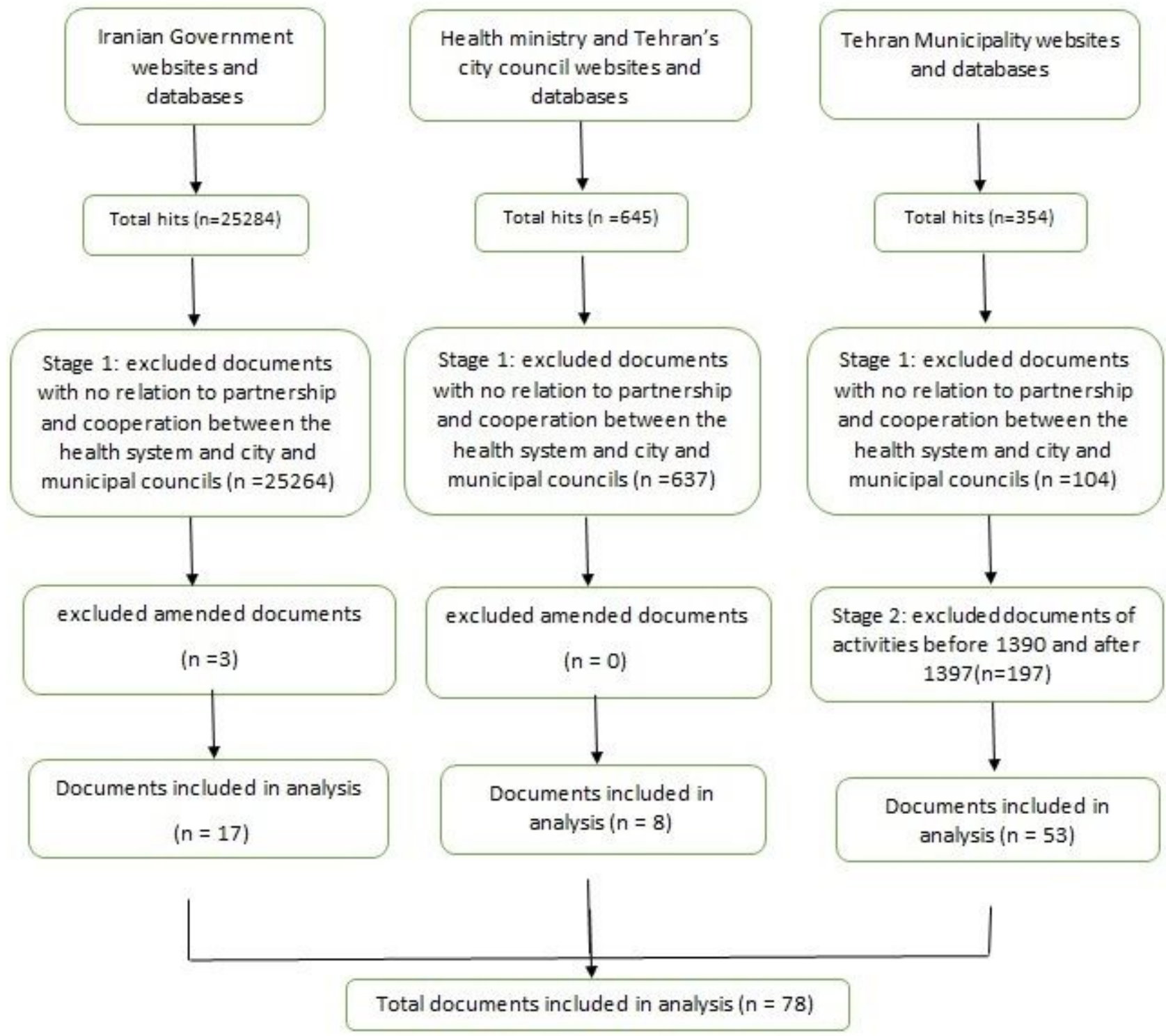

Figure 2

Document Selection 